Valiyeva A.G.

DOI: 10.25108/2304-1730-1749.iolr.2019.58.65-88

\title{
Legal basis of the grant of political asylum in the field of national and international law
}

\begin{abstract}
Mentioning the processes occurring all over the world, we started to observe more international relations moving to new levels, more people migrating in a massive way because of the regional chaos, because of the problems that are created as the results of natural disasters and wars. When countries cannot protect their citizens from chase, citizens are being forced to get away from their motherland, even their families.

It is named the legal basis of the grant of political asylum in the field of national and international law is researching to provide a political asylum and the problems related to it based on the international provisions. It helps foreigners and people who are not the citizen of the country to understand some words and some thoughts. Showing the types of chases that cause the need to political asylum, we analyze five major reservations that are intended in 28 July 1951 dated convention of UN called "About the position of immigrants". The solutions to the problems about giving an asylum to foreigner and non-citizens are given in this article.

It is examined national legislation on the provision of political asylum in the $\mathrm{AR}, \mathrm{RF}$, the US and a number of countries, and some comparisons have been made.
\end{abstract}

Keywords: foreigners and stateless persons; the right to political asylum; prosecution.

\footnotetext{
"Valiyeva Aynur Gahraman qizi - Researcher of the Department of "Foreigners' rights and migration" of the Institute on Law and Human Rights of the Azerbaijan National Academy of Sciences (Azerbaijan). E-mail: veliyevaa3@gmail.com
} 
Son dövrlərdə beynəlxalq münasibətlərin keyfiyyətcə yeni müstəviyə keçməsi, dövlətlər arasında baş verən müharibələrin, milli, irqi, regional münaqişələrin, fövqəladə vəziyyətlərin, eyni zamanda təbii fəlakətlərin doğurduğu problemlər nəticəsində əhalinin daha çox kütləvi şəkildə miqrasiyası müşahidə olunmağa başlanılmışdır. Belə ki,dövlətlər öz vətəndaşlarını yuxarıda qeyd edilən təqiblərdən qoruya bilmədikdə, insanlar öz doğma vətənindən, evindən, hətta ailəsindən belə uzaq yaşamağa məcbur olurlar.

Məqalənin predmetini milli və beynəlxalq hüquq sahəsində siyasi sığınacağın verilməsinin hüquqi əsasları təşkil edir. $\mathrm{Bu}$ məqalədə həm milli, həm də beynəlxalq hüquqda siyasi sığınacağın verilməsinin və onunla yaranmış problemlər araşdırılır.

Sığınacaq hüququ qədim dövrlərdən mövcud olan hüquqi konsepsiyadır və orta əsrlərdə şəxsin vətəndaşı olduğu ölkədə məruz qaldığ1 təqiblərdən yaxa qurtarmaq üçün başqa dövlətə və ya kilsəyə sığınması mənasında işlədilirdi. $\mathrm{Bu}$ hüquq hələ qədim misirlilər, qədim yunanlar və qədim ibranilər tərəfindən tanınmış və sonradan Qərbdə ənənəyə çevrilmişdir [7].

Müasir milli və beynəlxalq hüquqa görə siyasi sığınacaq əsasən milli, irqi, dini, siyasi baxışlarına və sosial mənsubiyyətinə görə öz ölkələrində təqibə məruz qalmış əcnəbilər və vətəndaşlı̆̆ı olmayan şəxslərə verilir.Ölkəmizdə siyasi sığınacaq alan əcnəbilərə və vətəndaşlığı olmayan şəxslərə Azərbaycan Respublikasının Miqrasiya Məcəlləsinin 3.0.1 və 3.0.2-ci maddələrində anlayış verilmişdir. Həmin məcəllənin 3.0.1-ci maddəsinə əsasən əcnəbi dedikdə, Azərbaycan Respublikasının vətəndaşı olmayan və başqa dövlətin vətəndaşlığına mənsub olan şəxs başa düşülür. Vətəndaşlığı olmayan şəxsdedikdə isəMiqrasiya Məcəlləsinin 3.0.2-ci maddəsinə əsasən heç bir dövlət tərəfindən onun qanununa əsasən vətəndaş hesab edilməyən şəxs başa düşülür [ 2 , s. 11].

Öz ölkəsində təqiblərə məruz qalan əcnəbilər və vətəndaşlığ olmayan şəxslər çıxış yolu kimi öz ölkəsini tərk etmək məcburiyyətində qalırlar. İlk öncə onlar 
sığınmaq üçün özlərinə müxtəlif ölkələrə müraciət edə və yaxud heç bir rəsmi icazə almadan qeyri-qanuni yollarla ölkəyə daxil olurlar.Qeyri-qanuni yollarla öz ölkəsindən başqa dövlətə sığınan əcnəbilər və ya vətəndaşlığı olmayan şəxslər çox vaxt müharibə aparılan ölkələrdən olur. Buna əyani misal olaraq, Suriya vətəndaşlarını göstərmək olar. Suriyada 2011-ci ilin mart ayında başlanan vətəndaş müharibəsi nəticəsində Suriya vətəndaşları başqa ölkələrə üz tutmuş və sığınacaq axtarmaq məcburiyyətində qalmışlar. Suriya vətəndaşları daha çox Türkiyə, İordaniya, Misir, Livan və s. ölkələrə sığınacaq üçün müraciət etmişlər. Suriya vətəndaşlarına Türkiyə və Suriya sərhədində Ol-Salama adlı yerdə sığınacaq düşərgələri yaradılmışdır [8].

Oslində sığınma nədir və sığınma dedikdə nə başa düşülür? Sığınma dedikdə, təqiblərə məruz qalan şəxsin öz ölkəsindən başqa dövlətə gəlmiş və öz ölkələrinə qayıtmaq istəməyən və ehtiyat edən şəxslərə verilmiş hüquqi müdafiədir. Sı̆̆ınma irqi, dini, milliliyi, müəyyən bir sosial qrupun üzvlüyü və ya siyasi fikri nəzərə alınmaqla, ona qarşı tətbiq edilən zülmdən və ya əsaslı təqibdən qorxduğu üçün öz ölkələrinə qayıda bilməyən və ya istəməyən insanlar üçün nəzərdə tutulur.

Sığınacaq sözünün mənası isə gizlənmək, sığınmaq üçün yerdir. Adından göründüyü kimi, siyasi sığınacaq "siyasi və sığınacaq" adlı iki sözün birləşməsindən əmələ gəlmişdir. "Siyasi” ərəb sözü olub mənası siyasətlə bağl1, siyasətə aid olan, siyasəti həyata keçirməklə bağlı olan kütlələrin siyasi aktivliyi, siyasi fəaliyyəti və s. kimi başa düşülür [1, s. 166]. Siyasi sığınacaq dedikdə, öz ölkəsində müəyyən səbəblərə görə təqiblərə məruz qalmış və ya təzyiqlərlə üzləşən şəxsin başqa ölkədə yaşamasına və işləməsinə imkan verən hüquq hesab etmək olar.

İnsan Hüquqları haqqında Ümumi Bəyannamənin 14-cü maddəsinin 1-ci bəndində göstərilən tərifə əsasən "hər bir insanın təqibdən qorunmaq üçün başqa ölkələrdə sığınacaq axtarmaq və sığınacaqdan istifadə etmək hüququ vardır” [5, s. $12]$. 
Yuxarıda sığınacağa verilən anlayışdan görünür ki, təqibdən qorunmaq üçün insanlar siyasi sığınacaq axtarmaq məcburiyyətində qalırlar. "Təqib" sözünə verilmiş və ya ümumi qəbul olunmuş bir tərif yoxdur. Təqibin aşağıdakı kimi növlərini qeyd etmək olar: soyqırım; köləlik; işgəncə; qəddar və ya alçaldıcı, qeyriinsani rəftar; həyati təhlükələr; qeyri-qanuni saxlama; dolanışığını qazana bilməmək; ölkə daxilində təhlükəsiz səyahət edə bilməmək; şəxsin özəl həyatına qeyri-qanuni müdaxilə; normal əlçatımlı təhsilə çıxışa ciddi məhdudiyyətlər; pasport verilməməsi; daimi nəzarət; informasiyalı olmağa qarşı təzyiq; mülkiyyətin müsadirəsi və $\mathrm{s}$.

Onu da qeyd etmək istəyirik ki, BMT-nin "Qaçqınların statusu haqqında" 28 iyul 1951-ci il tarixli Konvensiyasının müddəalarına görə siyasi sığınacaq almaq istəyən şəxslərə və onlara siyasi sığınacağın verilməsi üçün 5 əsas şərt qəbul olunmuşdur. Bunlar əsasən aşağıdakılar hesab olunur:

1) İrqi; 2) dini; 3) milli-etnik; 4) sosial qrupun üzvü olmasına görə; 5) siyasi fikirlərinə, siyasi fəaliyyətinə və s. təqib olunma nəzərdə tutulur. Beləliklə, siyasi sığınacağın verilməsinin əsas şərtlərinin ayrı-ayrılıqda təhlilinə baxaq:

1. Siyasi sığınacağın verilməsi üçün əsas şərtlərdən birincisi şəxsin irqi mənsubiyyətinə görə təqib olunmasıdır. İrqi mənsubiyyətinə görə təqib dedikdə, şəxsin dərisinin rənginə (qara, qırmızı) görə hakim irqin nümayəndələri tərəfindən onun təqib olunmasıdır;

2. Siyasi sığınacağın verilməsi üçün ikinci şərt isə şəxsin dini fikirlərinə görə təqib olunmasıdır. Dini fikirlərinə görə təqib olunma dedikdə, yəni burada şəxsin inandığ 1 və etiqat etdiyi dini baxışlara, fikirlərə görə təqib nəzərdə tutulur ki, təqib olunan şəxs üçün həyati təhlükə mövcud olur;

3. Milli-etnik mənsubiyyətinə görə təqib olunma dedikdə, şəxsin vətəndaş1 olduğu ölkədə milli-etnik mənsubiyyətinə görə təzyiqlərlə üzləşməsi milli-etnik təqib say1lır. 1988-ci ildə etnik təqib nəticəsində azərbaycanlılar öz ata-baba 
torpaqlarından didərgin olunmuşlar. Beləliklə, ölkəmiz 1989-ci ildə həmin siyasət nəticəsində daxili-xarici məcburi miqrasiyaya məruz qalmışdır;

4. Digər bir şərt isə sosial qrupun üzvü olmasına təqib olunmadır. Hansı ki, müəyyən sosial qrupa aid olan şəxslər (cinsi azlıqlar, insan alveri qurbanları) vardır ki, onlar yaşadığı ölkədə təqib olunur və zorakılığa məruz qalırlar və həmin ölkədə yaşamaları üçün real olan təhlükə mövcud olur;

5. Sonuncu şərt isə şəxsin siyasi fikirlərinə, siyasi fəaliyyətinə, siyasi görüşlərinə görə təqib olunma nəzərdə tutulur. Belə ki, siyasi fikirlərinə görə daha çox təqibə məruz qalanlar əsasən siyasi fəallar, jurnalistlər və siyasətçilər olur.

Təbii ki, siyasi sı̆̆ınacaq əldə etdikdən sonra həmin şəxs barəsində bir sıra hüquqi nəticələr yaranır. Bu hüquqi nəticələrə uyğun olaraq qeyd etmək istərdik ki, siyasi sığınacaq alan şəxs dövlətə giriş və həmin ölkədə yerləşməyə icazənin verilməsi, təhlükəsiz yaşamaq hüququ, şəxsin təqibə məruz qala biləcəyi dövlətə verilməməsi və sürgün edilməməsi və. s hüquqları yaranır.

Habelə, ölkəmizdə siyasi sığınacağın verilməsi konstitusiya normaları ilə tənzimlənir. Bu barədə Azərbaycan Respublikasının Konstitusiyasının 70-ci maddəsində göstərilir ki, hamılıqla qəbul edilmiş beynəlxalq hüquq normalarına uyğun olaraq Azərbaycan Respublikası əcnəbilərə və vətəndaşlı̆̆ olmayan şəxslərə siyasi sığınacaq verir. Siyasi əqidəsinə görə, Azərbaycan Respublikasında cinayət sayılmayan əmələ görə təqib edilən şəxslərin başqa dövlətə verilməsinə yol verilmir. Həmin maddənin II-ci hissəsinə əsasən Azərbaycan Respublikasında əcnəbilər və vətəndaşlığı olmayan şəxslərə siyasi sığınacaq verilir [3, s. 23].

Beləliklə, siyasi sığınacağın verilməsi məsələlərini həll etmək səlahiyyəti Azərbaycan Respublikası Prezidentinə aid edilir. Bu səlahiyyət Azərbaycan Respublikasının Konstitusiyasının 109-cu maddəsinin 21-ci bəndində nəzərdə tutulmuşdur [3, s. 40].

Siyasi sığınacağın iki formasına rast gəlmək olar: ərazi və diplomatik sığınacaq. Beləliklə, dövlətin hər hansı bir şəxsə siyasi sığınacaq verməsi bir sıra 
beynalxalq-hüquqi nəticə doğurur: dövlət sığınacaq verdiyi şəxsi geri verə bilməz; dövlət sığınacaq verdiyi şəxsə onun hər hansı bir ölkədə hüquqları pozulan zaman diplomatik müdafiə ilə təmin edə bilər; dövlət sığınacaq verdiyi şəxsin fəaliyyətinə görə məsuliyyət daşıyır, yəni o, həmin şəxsin tərk etdiyi dövlətə qarş1 zorakılıq aktları törətməsinə yol verməməlidir [6, s. 30].

Siyasi sığınacaq hüququ 1967-ci il tarixli "Orazi sığınacağı haqqında Bəyannamə” ilə tənzimlənir. Siyasi sığınacaq hüququndan sui-istifadə edilməməsi üçün ona müxtəlif məhdudiyyətlər qoyulmuşdur. BMT-nin Nizamnaməsində nəzərdə tutulmuş məqsəd və prinsiplər əleyhinə siyasi cinayətlər törətmiş şəxslərə siyasi sığınacaq hüququ verilmir. Bu hüquq terror aktları törədən, irqi ayrı-seçkilik çıxışları edən, ictimai qaydanı pozan və əhalinin sağlamlığı, mənəviyyatı üçün təhlükəli olan şəxslərə şamil edilmir. Siyasi sığınacaq almış şəxslərlə bağlı "nonrefoulement" prinsipi əsas götürülür ki, bu prinsipə görə də siyasi sığınacaq almış şəxs ərazisində onu təhlükə gözləyən dövlətə qaytarıla bilməz [4, s. 303].

Orazi sığınacağı dedikdə, bu və ya digər səbəbdən təqib olunan şəxsin başqa ölkənin ərazisində müdafiə olunmasıdır. Beynəlxalq hüquqda ərazi sığınacaq hüquq məsələsini tənzimləyən vahid məcəlləşdirilmiş sənəd mövcud olmadığına görə bu sahədəki mövcud normalar da tövsiyə xarakter daşıyır. Beynəlxalq Hüquq Komissiyasının ciddi səylərinə baxmayaraq, ərazi sığınacaq hüququnun məcəlləşdirilməsi mümkün olmayıb və nəticədə yalnız BMT Baş Məclisinin 2312 saylı (XXII) 14 dekabr 1967-ci il tarixli qətnaməsi ilə "Orazi Sığınacağı haqqında Bəyannamə" qəbul edilmişdir.

Diplomatik sığınacaq hüququ isə öz xüsusiyyətlərinə görə dövlətin hüququdur. Belə ki, diplomatik sığınacaq, təqib olunan şəxslərin səfirlik və konsulluqların binalarında himayəyə götürülməsidir. Diplomatik sığınacaq hüququ 1961-ci il Vyana Konvensiyası ilə tənzimlənir. Beləliklə, diplomatik sığınacaq hüququnun alınmasına dair bir misal qeyd edək: Wikileaks internet səhifəsinin yaradıcısı və redaktoru olan Julian Assange Amerika Xarici işlər Nazirliyi ilə 
Səfirlik və Konsolluqları arasındakı yazışmaları və ABŞ-ın digər dövlətlərlə münasibətlərinə dair mühüm faktları özündə əks etdirən sənədləri internetdə yaymışdır. İsveçdə yaşadığı dövrdə cinayət törətmişdir. İngiltərədə olduğu dövrdə isə ona İsveç dövləti tərəfindən törətdiyi cinayətə görə cinayət işi açılmışdır. Beləliklə, İsveç ölkəsi tərəfindən son qərara əsasən Assangen İsveç ölkəsinə qaytarılması nəzərdə tutulmuşdur. Assange İsveç ölkəsi tərəfindən qəbul edilən qərarla razılaşmamış və apellyasiya şikayəti vermişdir, lakin onun şikayəti təmin edilməmişdir. Assange Amerika tərəfindən casusluqda ittiham olunmaqla, eyni zamanda İsveçə qaytarılması vəziyyətində olan və Amerikaya qaytarılması müddətinin müəyyən olunmasına qədər Londonda Ekvador Səfirliyinə diplomatik sığınacaq üçün müraciət etmiş̧dir. Ekvador Səfirliyi 19 iyun 2012-ci ildə Assangen müraciətini qəbul etmişdir. Ekvador səfirliyi Assangen Amerikaya qaytarılması vəziyyətində olan siyasi bir məhbus olduğunu və casusluqda ittiham olunan Assangen təqiblərdən və pis rəftara məruz qalaraq tutulacağını ifadə edərək diplomatik sığınacaq verdiyini qeyd etmişdir [9].

Qeyd etmək istəyirik ki, bir sıra Avropa (AFR, İtaliya, Fransa, İsveç) ölkələrində siyasi sığınacağın verilməsinə dair beynəlxalq hüquqla müəyyən olunmuş qaydalar mövcuddur. Həmin qaydalar və prosedurlar əsasında siyasi sığınacaq axtaranlara "siyasi sığınacaq statusu" verilir. Siyasi sığınacağın verilməsində göstərilən təqib dövlət orqanları tərəfindən olmalıdır. Lakin, bəzi hallarda hakimiyyət tərəfindən dəstəklənən siyasi partiya, bəzi ölkələrdə hətta bir ailə, bir dini qurum, Qeyri-Hökumət Təşkilatları da bu cür təqibləri edə və təhlükə mənbəyi ola bilərlər. Bu halda şəxs ölkəsində polisin və ya digər qurumların həmin şəxsi qorumaq gücündə olmadıqları haqda məlumatlar verməli, faktlar göstərməli və sübutlar təqdim etməlidir. Müvafiq dövlət orqanı tərəfindən şəxsə qarş1 təhdidlərin olub-olmadığını da araşdırılır. Bu təhdidlərin hər hansı xəstəliyin yaranmasında, həyat şəraitinin, iş yerinin itirilməsində, şəxsin özünə və yaxınlarına tətbiq olunan zorakılığın nəticələrini də ifadə edə bilər. Eyni zamanda sığınacaq 
istənilən ölkədən əvvəl, ərazisindən istifadə olunan ölkələrdə sığınacaq üçün müraciət edilməməsinin səbəbləri də göstərilməlidir. Həmin ölkənin şəxsin təhlükəsizliyinə təminatının olmadığını əsaslandırılmalıdır.

Belə ki, müraciət daxil olduğu andan dərhal qeydiyyata alınır və müəyyən müddətdən sonra fərdi qaydada müraciət edən şəxs müsahibəyə dəvət olunur. Müsahibənin məzmunu məxfi saxlanılır və heç kimə açıqlanmır. Verilən ifadəyə görə də, şəxsə sığınacağın verilib-verilmədiyi haqqında qərar qəbul edilir. Ogər sığınacaq üçün ölkəyə daxil olan zaman müsahibəyə dəvət olunan günə kimi başqa məmura da müsahibə verilmişdirsə onlar da üzləşdirilir. Bu isə ifadənin düzgünlüyünü və dəqiqliyini müəyyən edir. Çünki, gələcək də şikayətin olunması üçün bu ifadə əsas götürüləcək və daha çox o mübahisələndiriləcək. İfadənin verilməsi və şəxsin sığınacaq üçün müraciət etmək səbəblərinin qeyd olunması baxımından çox önəmlidir. İfadə verməyə gedilən zaman təqibi təsdiq edən sənədlər götürülməlidir. Belə ki, müsahibə zamanı 25 və ya daha çox sual verilə bilər. Bu suallar şəxsiyyətin müəyyənləşdirilməsi və müraciət olunan ölkəyə hans1 yolla gəlinməsilə bağlı olur. İfadə ilkin verilən qeydlərə uyğun olmalıdır. Eləcə də ölkəni tərk olunmasına səbəb olan hallar haqqında danışılmalıdır. Ölkədə hücum və təqiblərin və ya təhlükə yaradan halların (həbs olunma, pis rəftar, fərqli münasibət, işgəncə və s.) qaçışa səbəb olan konkret halları ardıcıllıqla göstərilməlidir. Müsahibə vermə prosesi başa çatandan sonra verilən ifadəni imza ilə təsdiq edilməlidir [10].

Qeyd etmək lazımdır ki, siyasi sığınacaq hüququ milli və beynəlxalq hüquq normaları ilə tənzimləndiyi kimi, bir sıra inkişaf etmiş dövlətlərdə o cümlədən Rusiya Federasiyasında siyasi sığınacaq statusunun verilməsi məsələsi Rusiya Federasiyasının Prezidentinin 1997-ci il 21 iyul tarixli 746 nömrəli Sərəncamı ilə təsdiq edilmiş "Rusiya Federasiyasının siyasi sığınacaq verilməsi qaydası haqqinda" Өsasnamə ilə tənzimlənir. Өsasnamədə göstərilən qaydalar Rusiya Federasiyasının xarici vətəndaşlarına və vətəndaşlığı olmayan şəxslərə siyasi 
sığınacaq verilməsi qaydasını müəyyən edir. Həmin Đsasnamədə göstərilmişdir ki, siyasi sığınacaq Rusiya Federasiyasının Konstitusiyasına və bu Әsasnaməyə uyğun olaraq, Rusiya Federasiyasının beynəlxalq hüququn ümumi qəbul edilmiş prinsipləri və normaları əsasında Rusiya Federasiyasının dövlət maraqları nəzərə alınmaqla, xarici vətəndaşlara və vətəndaşlığı olmayan şəxslərə verilir. RF-də siyasi sığınacağın verilməsi haqqında müraciətləri Rusiya Federal Miqrasiya Xidməti qəbul edir.

Rusiya Federasiyasında siyasi sığınacaq almaq istəyən şəxslər ölkəyə daxil olduqları vaxtdan 7 gün müddətində Daxili İşlər Nazirliyinə, Baş Polis İdarəsinə və yaxud gəldikləri ərazinin yerli polis idarələrinə bu barədə müraciət etməlidir.

Әcnəbilər və vətəndaşlığı olmayan şəxslər siyasi sığınacağın verilməsinə görə Rusiya Federasiyasına müraciət etdikdə Rusiya Federasiyasının Daxili İşlər Nazirliyi Rusiya Federasiyasının Xarici İşlər Nazirliyinin və Rusiya Federasiyasının Federal Təhlükəsizlik Xidmətinin sorğu ilə müraciət edir. Sorğunun nəticələrini soruşduqdan sonra Rusiya Federasiyasının Prezidenti yanında Vətəndaşlıq Məsələləri üzrə Komissiyaya siyasi sığınacağın verilməsinin mümkünlüyü və məqsədəuyğunluğu barədə müraciət edir. Rusiya Federasiyasının Prezidenti yanında Vətəndaşlıq Məsələləri üzrə Komissiya onlara edilmiş müraciətləri və materialları nəzərdən keçirir və hər bir ərizə üçün öz təkliflərini Rusiya Federasiyasının Prezidentinə təqdim edir. Rusiya Federasiyası tərəfindən siyasi sığınacaq verilmiş şəxs, habelə onun ailə üzvləri şəxsin ərizəsi əsasında standart şəhadətnamə verilir.

Rusiya Federasiyası tərəfindən siyasi sığınacaq verilmiş şəxsə aşağıdak1 hallarda siyasi sığınacaq hüququnu aşağıdakı hallarda itirir:

1. Öz ölkəsinə qayıtdıqda;

2. Üçüncü bir ölkəyə getdikdə;

3. Rusiya Federasiyasının ərazisində siyasi sığınacaqdan könüllü imtina etdikdə. 
Siyasi sığınacaq itkisi Rusiya Federasiyasının Xarici İşlər Nazirliyinin və Rusiya Federasiyasının Federal Təhlükəsizlik Xidmətinin nəticələrinə əsasən Rusiya Federasiyasının Daxili İşlər Nazirliyinin tövsiyəsi ilə Rusiya Federasiyasının Prezidenti yanında Vətəndaşlıq Komissiyası tərəfindən müəyyən edilir. Müraciət edən şəxs cinayət törətmişsə və ona qarşı məhkəmənin qəti hökm varsa şəxs barəsində dövlət təhlükəsizliyi səbəbləri ilə Rusiya Federasiyasının ona verdiyi siyasi sığınacaqdan məhrum edilə bilər. Həmin şəxs Birləşmiş Millətlər Təşkilatının məqsəd və prinsiplərinə zidd olaraq fəaliyyət göstərdiyi zaman siyasi sığınacaqdan məhrum edilməsi barədə Rusiya Federasiyasının prezidentinin fərmanı ilə qəbul edilir [11].

Digər bir dövlət kimi ABŞ-da siyasi sığınacağın verilməsi məsələsinə nəzər yetirək: ABŞ-da siyasi sı̆̆ınacağın verilməsi məsələsində müddətə dair bəzi istisnaların mövcud olmasına baxmayaraq, siyasi sığınacaq almaq istəyən şəxs ölkəyə daxil olduğu andan bir il ərzində ərizə ilə müraciət edə bilər. Siyasi sığınacaq istəyən şəxs ərizəsini ABŞ-ın Vətəndaşlıq və İmmiqrasiya Xidmətlərinə təqdim etməlidir. ABŞ-da siyasi sığınacağın verilməsi üçün ABŞ qanunvericiliyinə uyğun olaraq müəyyən sənədlər tələb olunur: bu sənədlər tibbi arayış və hüquq mühafizə orqanları tərəfindən onun barəsində qəbul olunmuş sənədlər (çağırış, qərar), siyasi sığınacaq almaq üçün ərizə verən şəxsin öz ölkəsində təqib olunduğunu təsdiq edən qohumlarının yazılı arayışları və s. nəzərdə tutulur. Đgər nəzərdə tutulan sənədlər siyasi sığınacağın verilməsi üçün kifayət qədər yetərli olmasa onda siyasi sığınacağın verilməməsi barədə qərar qəbul edilir. Siyasi sığınacağın verilməməsi barədə qərardan siyasi sığınacağ əldə etmək istəyən şəxs İmmiqrasiyanın Apelyasiya Şurasına və müvafiq ABŞ Cəza Məhkəməsinə şikayətlə bağlı müraciət edə bilər.

Qeyd etmək istəyirik ki, əcnəbilər və vətəndaşlığı olmayan şəxslərin siyasi sığınacaq statusunun alınmasından sonra onların sığınacaq aldığı ölkədə adaptasiya məsələsi nəzərdə tutulmalıdır. Sığınacaq statusunun alınması nəticəsində şəxs öz 
ölkəsinin adət-ənənələrindən yad və uzaq bir mühitdə yaşamaq hüququ əldə edir ki, bu da öz növbəsində əcnəbilərə və vətəndaşlığı olmayan şəxslərə müəyyən çətinliklər törədə bilər. Ölkəmizdə sığınacaq alaraq daimi yaşamaq hüququ əldə etmək istəyən əcnəbilər və vətəndaşlığı olmayan şəxslər üçün müsahibə mərhələsinə qədər Azərbaycan Respublikası Dövlət Miqrasiya Xidmətinin Təlimtədris mərkəzi tərəfindən Azərbaycan dilinin, tarixinin, mədəniyyətinin, həmçinin əcnəbilərin və vətəndaşlığı olmayan şəxslərin hüquq və vəzifələri ilə bağl1 qanunvericiliyin öyrənilməsi məqsədilə kurslar təşkil edilir. Buna görə də, siyasi sığınacaq statusu almış əcnəbilərə və vətəndaşlığı olmayan şəxslərin ölkəmizin dilini, tarixini, mədəniyyətini, adət-ənənələrini tam şəkildə öyrənmələri və ölkəmizə adaptasiya olunmaları üçün bu kursların bir neçə il davam etdirilməsini təklif edərdik.

Sonda belə nəticəyə gəlmək olar ki, başqa ölkələrdənsiyasi sığınacaq istəyən şəxslərlə bağlı müəyyən problemlər mövcuddur. Bu problemlərdən biri dəsiyasi sığınacaq istəyən şəxslərlə bağlı pis rəftar edilməsi məsələsidir. Bəzi hallarda isə onlarsiyasi sığınacaq verilmədən təqib olunduqları öz ölkələrinə qayıtmaq məcburiyyətində qalırlar. Siyasi sı̆̆ınacaq istəyən şəxslərlə pis rəftarın nümunələri kimi aşağıdakıları göstərmək olar:

- qeyri-qanuni yollarla ölkə ərazisinə gəlmiş və siyasi sığınacaq axtaran şəxslərin heç bir qanuni əsas olmadan dustaqda saxlanılması zamanı onlara tətbiq edilən fiziki zorakılıq;

- dustaq olduğu zaman kobud istintaq prosedurları.

Beləliklə, yuxarıda sadalanan hallar siyasi sığınacaq istəyən şəxslərlə pis rəftar zamanı yaranmış problemlər hesab olunur. Digər bir problem isə onların hüquqları ilə bağlıdır ki, sığınacaq istəyən şəxslərin ərizələrinin müvafiq orqan tərəfindən müzakirə olunub yekun qərar çıxarılan müddətə qədər onlar müəyyən hüquqlardan istifadə etmək imkanına malik olmurlar. Buna görə də onlar bir xeyli məhdudiyyətlər və maneələrlə üzləşə bilirlər. 


\section{References}

1. Agasiyev R.M. Azerbaycan Respublikasinda Acnebilerin ve vetendashligi olmayan shehslerin huquqi statusu [Legal status of foreigners and stateless persons in Azerbaijan Republic]. Baku, 2018, 364 p.

2. Azerbaycan Respublikasinn Miqrasiya Mecelləsi [Code of Mirgation of Azerbaijan Republic]. Baku, 2018, 62 p.

3. Azerbaycan Respublikasinin Konstitusiyasi [Constitution of Azerbaijan Republic]. Baku, 2017, 92 p.

4. Asgerov Z. Konstitusiya huququ. Derslik. [Constitutional Law. Textbook]. Baku, 2006, p. 697.

5. Huquq Muhafize Orqani Emekdashinin Insan Huquqlarina dair Melumat Kitabi, Beynelxalq Senedler, Azerbaycan Respublikasinin Normativ Hüquqi Aktlari, Azerbaycan Huquqshunaslari Konfederasiyasi [Informational book, International documents, Normative legal acts of Azerbaijan Republic, Confederation of Azerbaijan Jurisprudence for employee of law enforcement body concerning to human rights]. Baku, 2009, 564 p.

6. Nasirov V. Diplomatik siginacaq: beynelxalq huquqi problemler ve muvafiq helli usullari. Baki Dovlet Universiteti Telebe Huquq Jurnali № 1, 2015 [Diplomatic asylum: international legal problems and appropriate ways of resolution. Baku State University Students Law Journal]. Iss. no. 1, 2015, pp. 3034.

7. https://az.wikipedia.org/wiki/S\%C4\%B1\%C4\%9F\%C4\%B1nacaq_h\% C3\% BC ququ

8. https://az.wikipedia.org/wiki/Suriya_\%C9\%99halisi

9. https://uluslararasihukukcalismalari.wordpress.com/2015/06/20/assangeolayi-ve-diplomatik-siginma/

10. https://azeuronews.com/?p=29979

11. http://constitution.garant.ru/act/right/170008/ 